TITLE:

\title{
Biosynthesis of RNA Polymerase in Escherichia coli(Abstract_要旨)
}

$\operatorname{AUTHOR}(\mathrm{S})$ :

Taketo, Makoto

CITATION:

Taketo, Makoto. Biosynthesis of RNA Polymerase in Escherichia coli. 京 都大学, 1978, 医学博士

ISSUE DATE:

1978-03-23

URL:

http://hdl.handle.net/2433/221695

RIGHT: 
氏 名武藤住誠

学位の種類医学 博士

学位記番号医 博 第 493 号

学位授与の日付 昭 和 53 年 3 月 23 日

学位授与の要件 学位規 則 第 5 条第 1 項該当

研究科・尃攻医学研究科病理系尃攻

学位論文題目 Biosynthesis of RNA Polymerase in Escherichia coli

(大腸菌に於ける RNA ポリメラーゼの生合成)

諭文調査委員教主蔓)

\section{諞 交内容 の 要 旨}

大腸菌の DNA依存RNAポリメラーゼは $\alpha_{2} \beta \beta^{\prime}$ なるサブュニット構造を持つコア酵素と，乙れに ブユニットの添加したホロ酵素があって，RNA 合成の開始には $\sigma$ の存在が必須であるが，それ以後の RNA 鎖伸長反応は, コア酵素が触媒する。本醭素は代謝的に安定で, 野生株内では全く分解すること なく保持されるので, 細胞内に於ける本酵素の量的調節は, 本醉素の形成機構により一義的に支配され ており，その意味で本酵素の細胞内での形成機構とその制御を知ることは極めて重要な課題である。

試験管内再構成法によって, 本酵素は $\alpha_{2} \stackrel{\beta}{\rightarrow} \alpha_{2} \beta \stackrel{\boldsymbol{\beta}^{\prime}}{\rightarrow} \alpha_{2} \beta \beta^{\prime}$ (未熟型コア酵素) $\longrightarrow \mathrm{E}$ (活性コア酵素) の順 に各サブユニットの集合と末熟型コア酵素の活性化により形成されるととが解明されたが，ての様な段 階的で連続的な形成機構が，実際に in vivo でも起きているととを確認する為には，第一に， $\alpha_{2}, \alpha_{2} \beta$, $\alpha_{2} \beta \beta^{\prime}$ (未熟型コア酵素) などの形成中間体の in vivo での存在を確認するとと, 第二に, これらの各 形成段階に障害を来たした突然変異株を見出すととが必要であろう。

本論文は，上記第二点に関し，その様な形成不全突然变異株を発見した世界で最初の報告であると同 時に，生体内でも in vitro 再構成実験の場合と同じ過程で本酵素が形成されることの決定的な証明をし たことになる。

IV. の論文で扱っている大腸菌の高温感受性変異株 Ts4及T16は，Kirschbaumら，及 Khesin によ り分離され, 遺伝学的解析により， RNA ポリメラーゼの $\beta^{\prime}$ 遺伝子に，一方 Vの論文で披っている变異 株A2RTは， $\beta$ 遺伝子に突然変異を持つととが知られている。

これらの変異株に於ける各サブユニットの集合と, 未熟型コア酵素の活性化について調べる為, 以下 の実験を行った。

${ }^{3} \mathrm{H}$-ロイシンでパルス・ラベルした培養細胞の粗抽出液をグリセロール密度勾配遠心で分画し, 各画 分に抗 RNA ポリメラーゼ抗体を加えて得られた沈澱を，ポリアクリルアミドゲルの電気泳動にかけ， 各サブユニット蛋白の定量を行った。 
結果は，対照とした野生株 X240の場合，大部分のサブニニットが，14Sの活性ポリメラーゼの位置に 大きなピークをつくっており，他に $9 \mathrm{~S}$ 域と $4 \mathrm{~S}$ 域にそれぞれ $\alpha_{2} \beta$ 及び遊離 $\alpha$ サブュニットの小さな肩及 ピークを作るのに対し，変異株 Ts 4 では，9S の画分に $\alpha_{2} \beta$ 複合体の大きなピークが，変異株T16では $9 \mathrm{~S}$ 域に頂点を持ち，14S域まで尾を引く $\alpha_{2} \beta \beta^{\prime}$ (未熟型コア酵素) の大きなピークが観察される。又， $\beta$ 变異 株A2RTでは，9S 域に $\alpha_{2} \beta ， \alpha_{2} \beta \beta^{\prime}$ の双方がピークをつくり，更に4S域に，遊離 $\alpha$ サブユニットの大き

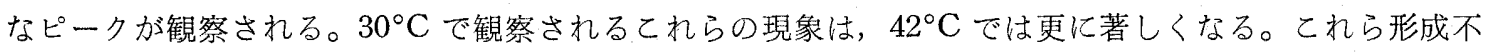
全変異株では， $\beta$ ， $\beta ， \sigma の$ 各サブユニットの分解が著しいが，(参考論文1参照）てれは， $\alpha_{2} \beta や \alpha_{2} \beta \beta^{\prime}$ あるいは遊離 $\sigma$ サブユニットなど，野生株ではわずかしか存在しない形成中間体や遊離サブユニットが 蓄積すると，生体内ではこれを異常な㔻白として認識し，分解する機構が存在するととを示唆している。 更にてれら変異株では，生体内活性酵素の量が不足することが予測されるが，野生株にくらべて各サブ ユニットの過剰合成が起きており（参考論文 1 参照），本酵素サブユニットの合成が，本酵素蛋白自身 により制御されている所謂自己制御（autogenous regulation)により調節されていることを示唆してい る。本論文での形成不全変異株に関する報告をまとめると下図の様に表される。

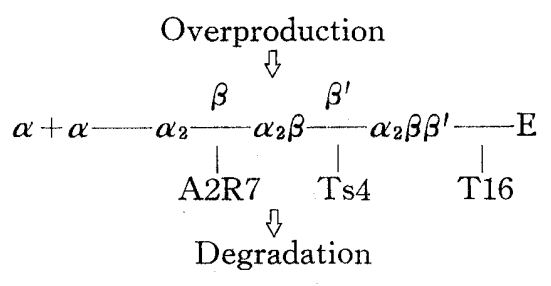

\section{論 交審 查の結果の要旨}

大晹菌RNAポリメラーゼ (RNA Pase)には $\alpha_{2} \beta \beta^{\prime}$ 構造をもつコア酵素と， $\alpha_{2} \beta \beta^{\prime}$ 構造をもつホ口醳 素があり，RNA合成開始には $\sigma, \mathrm{RNA}$ 鎖の伸長合成にはコア醳素が関与する。

本酵素は in vitro 再構成法で $2 \alpha \rightarrow \alpha_{2} \rightarrow \alpha_{2} \beta \rightarrow \alpha_{2} \beta \beta^{\prime}$ (未熟型コア酥素) $\rightarrow \mathrm{E}$ (活性コア酵素) の順にサブ ユニットが集合して形成されることが知られている。in vivo であ同様のステップを経て形成されるか 否かを，サブユニット笑然変異体を利用して調べたのが本論文の研究である。

$\beta$ 遺伝子の温度感受性 (ta) 变異株 $\mathrm{A}_{2} \mathrm{R}_{7}$ では $\alpha_{2} \beta$ 形成障害の結果 $\alpha$ が異常蓄積する。 $\beta$ 遺伝子の $\mathrm{ts}$ 変異 体 Tsl株とT16株では $\alpha_{2} \beta ， \quad \alpha_{2} \beta \beta^{\prime}$ が夫々異常蓄積すると共に， $\beta ， \beta ， \sigma$ 各サブュニットの分解が著しい。 これらの所見は in vivoでも in vitro と同じ経過でサブュニットの集合が進行して RNA Pase が形 成されることを示し，且正常では蓄積しないサブュニットを分解する機棈の存在を示唆する。

本研究は RNA Pase の生体内合成過程を始めて明かにすると同時に，そ机に関る制票機構について あ示唆を与えたもので，RNA 合成（転写）に関して寄与するとてろ極めて大きい。

よって，本論文は医学博士の学位論文として洒值あるものと認める。 